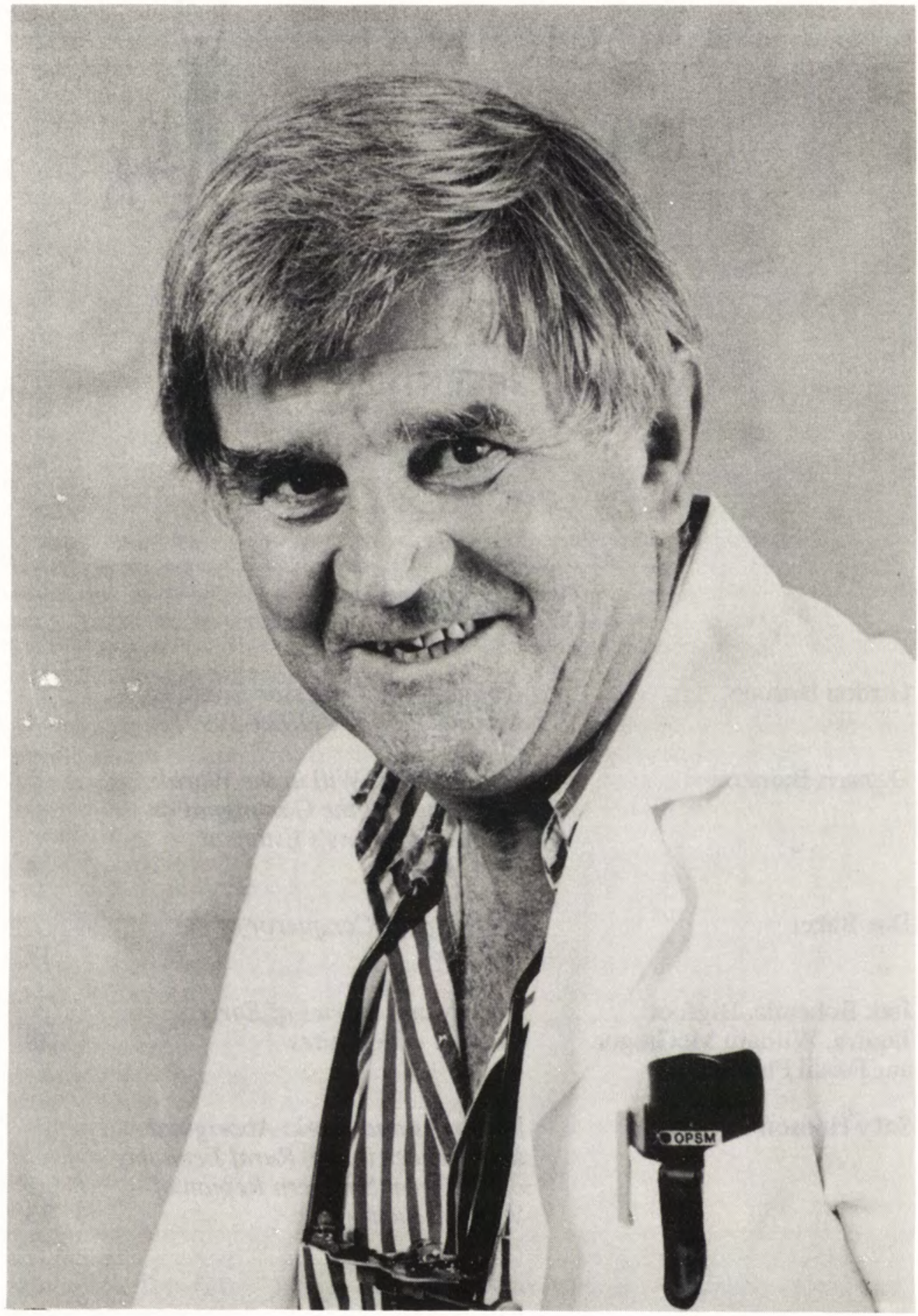

Professor Fred Hollows.

The Fred Hollows Foundation. 


\title{
OBITUARY FOR PROFESSOR FRED COSSOM HOLLOWS 1929-1993
}

\author{
Gordon Briscoe
}

Frederick Cossom Hollows was born in Dunedin, New Zealand, in 1929, the:second son of Joseph Alfred and Clarice Hollows. Fred was born at a time of great world economic turmoil into a family which was tolerant, Christian and socialist, with a long British labour heritage of political radicalism. His paternal grandfather, a coal-miner in Lancashire England, migrated to New Zealand in the 1870 s. This was a time when working people were locked in a great struggle for better living conditions, and a greater share of the wealth of what they produced from their labour. This struggle began in the 1830s during the early part of the great Industrial Revolution.

Fred's radicalism came from a Christian up-bringing sharpened by his early student days at Glenleith Church of Christ College, University of Otago, Dunedin, where he studied Divinity, Arts, and the physical sciences, and by his membership of the New Zealand Communist Party. Fred was a committed socialist when he went into the study of medicine in which he graduated at the University of Otago in 1956. Bourgeois customs and manners, however, were never allowed to come between the practice of medicine and humanism. Not long after graduating in medicine, he left for England. There, he worked as an epidemiologist under the famous Archie Cochrane, who was Professor of Respiratory Medicine at the Welsh National School of Medicine, and it was through him that he took an interest in eye diseases.

Fred's early epidemiological work on glaucoma, a blinding disorder related to increase in ocular pressure, was carried out mainly in Welsh mining towns. The findings of Fred's first research paper, 'Source of variation in tonometry', showed that earlier research was statistically unsound. The paper was delivered at Oxford in the early 1960 s. He published numerous articles in the 1960s and 1970s Two of these publications were 'Intra-ocular pressure, glaucoma suspects in a defined population', British Medical Journal of Ophthalmology, 1966, and 'A critical review of methods of detecting glaucoma', in Glaucoma, by J. Hunt, Edinburgh, 1969, both published with P.A. Graham. In his work on trachoma in Australia, he was responsible for the NTEHP Report, National Trachoma And Eye Health Program, Royal Australian College of Ophthalmologists, Sydney, 1980. ${ }^{1}$

Following research in England, Fred Hollows was appointed Associate Professor of Ophthalmology at the University of New South Wales and its Prince Of Wales Hospital at Randwick in the late-1960s. It was at this time that a number of political events were just taking shape.

One of these events was the emergence of the Federal Council for the Advancement of Aborigines and Torres Strait Islanders (FCAATSI) which, in the mid-1960s, spearheaded the campaign leading to the 1967 Referendum. The outcome of the Referendum changed

Division of Historical Studies, Research School of Social Sciences, Australian National University, Canberra.

The Editors acknowledge with gratitude the kindness of the Fred Hollows Foundation, Sydney, in providing two of their photographs of Fred Hollows for publication.

1 His life is covered in greater detail in Fred Hollows, Fred Hollows: An Autobiography, with Peter Corris, new edn., Kerr Publications, Balmain, NSW, 1992. 


\section{ABORIGINAL HISTORY 1993 17:1}

the Constitution in two respects: first, to allow Aborigines of 'full descent' to be counted in the national census (in reality all persons of mixed Aboriginal descent had been counted in every census since 1901, while people of 'full descent' were counted in some places but not published); and, second, to make it possible for the Commonwealth to make laws on behalf of Aborigines.

The other event was the emergence of the Gurintji Committee which drew Fred into the 'land-rights' and 'equal-wages dispute' fought by the trade unions and Aboriginal stockmen of the Northern Territory against the pastoralists and land owners of that state.

As a member of the Gurintji Committee (a committee made up largely of university students, left-wing socialists, communists and trade unionists) Fred saw some of the Gurintji stockmen's eye conditions in his Randwick clinic. These men were introduced to Fred by Frank Hardy, novelist, journalist, communist and political activist, who was also a member of the Gurintji Committee. Frank Hardy asked Fred to go to the Gurintji camps at Wave Hill in the Victoria River District of the Northern Territory. Fred became perplexed by the eye conditions he found there, conditions which had been seen only in African peoples.

On his return from Wave Hill Fred saw there were more complex conditions relating to the social and political circumstances of a subjugated people: poverty, eye diseases, poor health in general and a population prepared to tough it out against those who had disturbed the social structures they had had in place. Immediately on his return Fred became identified with the Gurintji struggle. He was also a committed anti-apartheid protestor. That was in 1970 when I first met him.

That meeting between us was in Redfern, at a meeting called by myself and Dulcy Flowers (a member of FCAATSI and a nurse of Torres Strait Islander descent). In attendance also were people such as Shirley Smith, Ross McKenna, John Russell of the South Sydney Community Aid and Fred, together with one of his medical students, Paul Beaumont. The story of the medical service development is well known so I need not recount that. I left the political scene in NSW to return to my home in the Northern Territory, and then to the Departments of Aboriginal Affairs and Health in Canberra. That was during the lattr part of 1973.

In 1974 Archie Kalokerinos made his now famous statement that Aboriginal blindness rates were the highest in the world. Fred contacted me to see if a program was possible to deal with the problem. With others, I encouraged him to talk in terms of a program to eradicate trachoma and other eye problems for both rural whites and Aborigines. Fred accepted the challenge. His proposal to the then Minister for Health, Dr Doug Everingham, included this principle and the objective that if operations were to take place they were be done as soon as possible and as close as possible to where people were living.

Before the Labor Government was dismissed on 11 November, 1975, the Minister for Health approved a grant of $\$ 1$ million to the College of Ophthalmology to conduct a rural eye health program. To Ralph Hunt's eternal credit he always supported the program even when threatened by the Queensland Government to ban it from re-entry to that state. Fred Hollows was the Director, and I was his Assistant Director, of the National Trachoma and Eye Health Program (NTEHP).

The program lasted as a national program and was split up into state-based services after the mid-1980s. The two-year screening program examined 105,000 people in 465 camps, country towns and large urban centres. Of that number, 15,000 Aborigines were treated, with 1,000 eye operations being performed on them. Fred spent considerable amounts of his own money and time supporting the Aboriginal health movement, from which he became increasingly alienated as it became part of the status quo. I advised him to 


\section{FRED COSSOM HOLLOWS}

spend more time with his new family and, later, to get involved in helping the socialist revolution in Eritrea.

Gradually, Fred succumbed to secondary infections from a cancer located in his kidney. Following an operation to remove one kidney Fred mounted an incredible fight. That struggle for life was both a very public one but equally it was very private. For me it was the kind of death that only great men and women come to experience. Fred Hollows became a great Australian. He did so because he was a socialist and a truly skilful eye surgeon, a sound medical epidemiologist and an eternal student of politics, medicine and socialism. Fred delighted in the argument of new ideas and new theories of interpreting the world. Very near to the end of his life he used all these skills to object to the way males who practised anal sex had monopolised the debate on the adequacy of AIDS policies.

Fred argued that AIDS was predominantly a problem among homosexuals and that government health authorities had given in to the 'gay' lobby over the issue. He said it was not good enough to promote 'safe sex' and then to tolerate anal intercourse and penetrative sex between HIV positive people.

AIDS policy and the effects of AIDS, he also argued, would have a catastrophic effect upon Aboriginal young and traditional community 'blood-letting' practices in some parts of rural Australia. It was gratifying to know that Fred's efforts to change the 'bull-nosed' way the Labour Government acted was his triumph. It was a triumph over personal threats made to himself and his family, over personal vilification by the 'gay' lobby and over anarchistic activities against him during his efforts to raise money for his support of the revolution in Africa and his program. He did it when Government funded bodies refused to speak out against the prospect that young Aboriginal migrants moving to the city for work which did not exist would turn to male prostitution for large sums of money from wealthy homosexuals, many of whom died in comfort and with public sympathy, while the ignorant Aboriginal youths would die a horrible death alone and in public disgrace. These are things which Fred fought for. These are the things which made Fred Cossom Hollows a great human being and a great humanist.

Professor Fred C. Hollows, as that great Aboriginal woman Mrs ('Mum Shirl') Smith always called him, was survived by his three brothers, John, Colin and Maurice, his wife Gabi, and his seven children, Ben, Tanya, Cam, Emma, Anna, Rosa and Ruth. He was given state funerals on Monday, 16 February, in both Sydney and Brisbane. His body was laid to rest in the Bourke cemetery, New South Wales, on Wednesday, 17 February, 1993, attended by many Aboriginal and other friends. It is unfashionable to refer to people these days as being 'the friend of Aborigines', but for Fred Hollows that is what he was. He was without racial prejudice and he knew more Aborigines, and entered their camps, than most other people. Fred lived up to his word in that he left the world a better place for having lived, and we will never see his like again. 